\title{
Numerical studies of soil base deformations from reconstructed multi-storey building to nearby buildings
}

\author{
Ilisar Mirsayapov ${ }^{1}$, Ildus Shakirov ${ }^{1}$, and Daniya Nurieva ${ }^{* 1[0000-0001-5110-2347] ~}$ \\ ${ }^{1}$ Kazan State University of Architecture and Engineering, 420043 Kazan, Russia
}

\begin{abstract}
During the building reconstruction with floors addition, there is a need to evaluate the building frame and foundation soil bearing capacity, especially if there are deviations from the design parameters. As a result of the field and numerical studies, we determined the basic change patterns in the stress-strain state of the 12-storey building load-bearing structures with a monolithic reinforced concrete frame due to uneven pile foundation deformation. We also found the influence degree of the existing deviations from the design parameters to the structures bearing capacity. The research results can be applied in reconstruction conditions with a significant increase in the load on the existing load-bearing elements of the building and on the pile foundation.

Keywords. Groundbase, pile-plate foundation, bored pile, bearing capacity, monolithic frame.
\end{abstract}

\section{Introduction}

To date, the pile-raft foundations are one of the most effective developments in the foundation engineering field [1-19]. They successfully apply in the design of multi-storey facilities on sites with unfavorable geological conditions, so far as they have an increased bearing capacity [2, 20-24]. However, in recent times, it is quite often in the construction of such foundations, there are cases of deviation from design solutions, which can lead, despite their high distribution capacity, to the uneven settlements development and, as a result, damage to the above-ground structures [1,3,9-14]. In such conditions, it is important to carry out full-scale and numerical researches of the building load-bearing frame stress-deformed state in order to assess their residual resource and the necessity for reconstruction (strengthening). A large number of works are devoted to the reconstruction of buildings and structures [4, 15-19]. But these sources do not consider the influence of the foundation with piles of various lengths on the above-ground structure behavior. In this regard, it is relevant to consider the building model in the form of a single system «building - foundation - soil», taking into account the immediate features of the pile foundation.

\footnotetext{
*Corresponding author: danm_n@mail.ru
} 


\section{Materials and methods}

The researched twelve-story administrative building was erected at the beginning of the $21^{\text {st }}$ century. In terms it has a square shape with beveled corners. The building is made with a rigid load-bearing frame system from monolithic reinforced concrete, with reinforced concrete beam slabs and a stiffening core, where passenger and freight elevators are placed. The building foundation is designed from the pile-raft made from reinforced concrete bored piles with a diameter $800 \mathrm{~mm}$ and reinforced concrete raft grillage with a thickness $1200 \mathrm{~mm}$. The pile field plan is shown in Fig. 1.
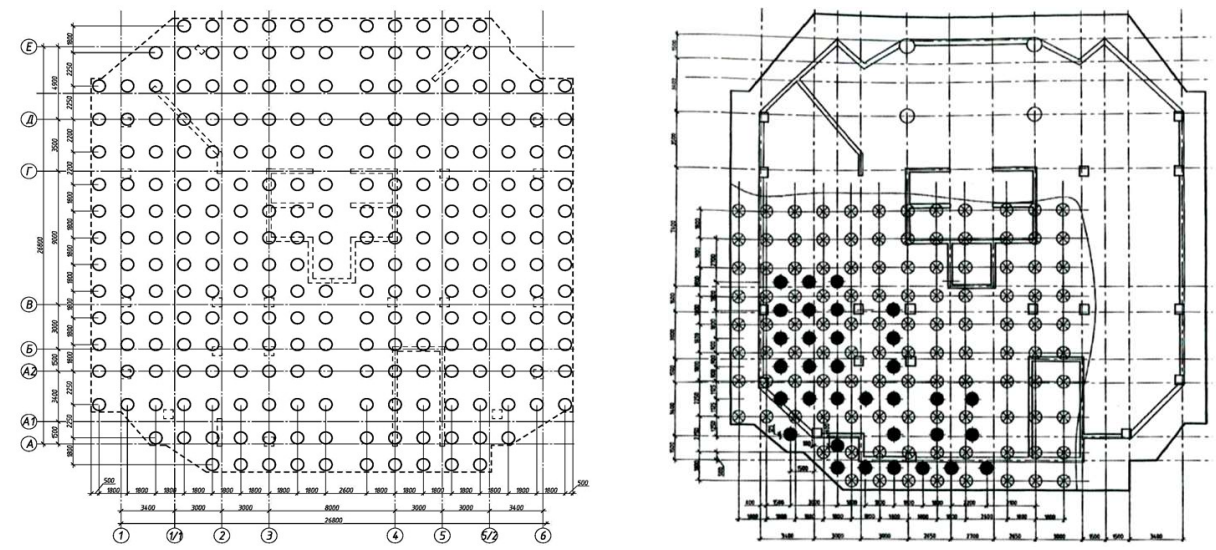

Fig. 1. The pile foundation plan according to the project solution and strengthening scheme with soilcement pile.

The pile-raft foundation during construction was performed with significant deviations from the project - under a part of the building (in axes 1-4 / A-g) piles have a length of $5.4 \mathrm{~m}$ instead of a design of $10 \mathrm{~m}$. Implementation of the pile field with the indicated deviations led to the following changes: the soil base uneven deformation and settlement; the raft grillage uneven and additional deforming; the tilt both of the raft grillage and the building as a whole. Due to the uneven deformation and tilt of the raft grillage in the building load-bearing structures, there were additional (unaccounted in design) forces and stresses, which led to the formation and development of cracks in the frame elements and to the deformed (non-design load) framework performance scheme during operation. Due to the deformations and building tilt in the short piles direction, the appearance of the cracks in the frame crossbars because of non-calculated tensile stresses, in the future foundations we introduced strengthening in the short piles zone with a soil-cement pile with diameter $600 \mathrm{~mm}$ and $10 \mathrm{~m}$ long (Fig. 1).

Strengthening the pile foundation by the introduction of soil-cement piles made it possible to restore the bearing capacity of the foundation soil to design values. However, this approach has not allowed to eliminate additional settlement, besides this, the elasticity modulus of soil-cement piles is significantly less than the elasticity modulus of reinforced concrete piles, which leads to the emergence and development of additional foundation soil settlement, additional movements and efforts in the frame load-bearing structures and in the raft grillage. When forecasting loadbearing capacity and the evaluation of the forecasted building residual life for reconstruction and subsequent operation it is necessary to take into account the factors mentioned above.

\subsection{Construction site engineering and geological conditions}

The engineering and geological conditions of the building site are characterized by inconsistency on the soils layers strike in the area and the depth, the inhomogeneity of their 
composition and state. The research area refers to the Bugulminsk-Bellebevsk elevated plateau with deep erosion dismemberment. The site, where the building is located, is situated within the left-bank terrace of the valley St. Zai River. According to the engineering and geological survey results, used in project development of the building pile foundation, alluvial-delulvial quaternary deposits and Upper-Permian eluvial deposits are included into the geological structure of the site. From the surface they are covered with industrial deposits of modern Quaternary Period (Fig. 2). During surveys, underground waters are not detected.
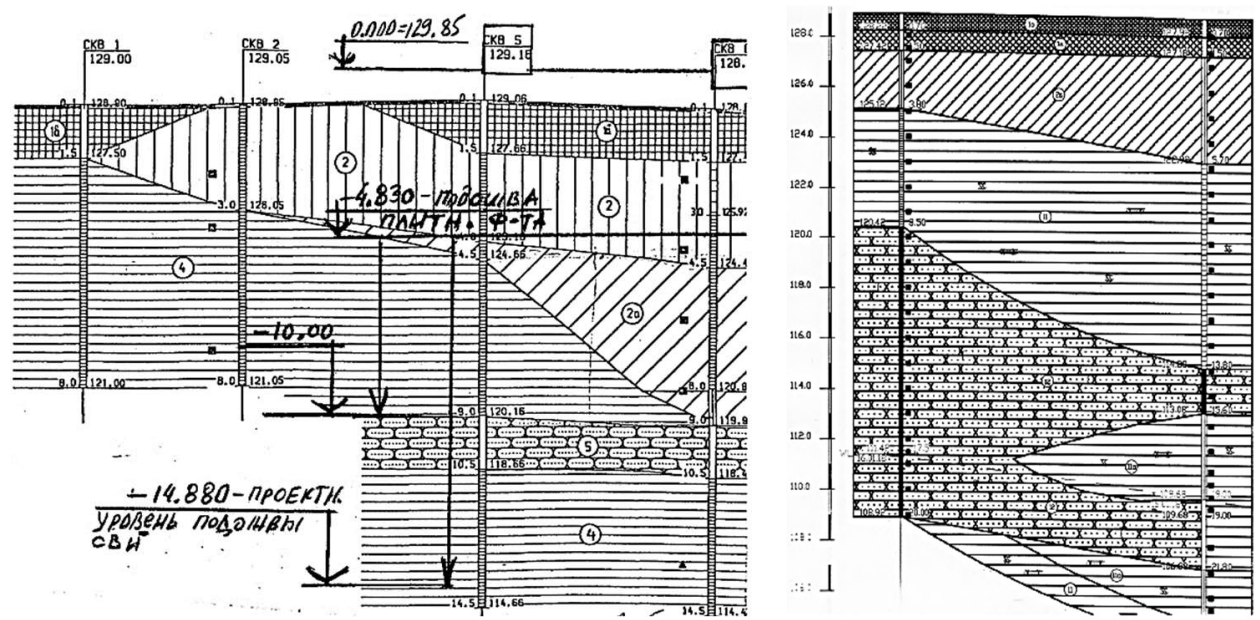

Fig. 2. Engineering and geological cross-section 2000 and 2018.

The geological and lithological structure of the site includes:

- technogenic bulk soils that are distributed over the entire platform, the thickness of bulk soils up to $1.6 \mathrm{~m}$;

- clay loam from a solid to a low-plasticity consistency with a thickness from 2 to $7.5 \mathrm{~m}$, which have settlement properties at the top of the soil profile;

- clay argillite-like, solid consistency, with a thickness of up to $7.3 \mathrm{~m}$;

- sandstone, fine grain, low strength.

The research conducted in the study of the building stress-strain state in 2018 indicates the increase in humidity and deterioration in the clay loam state. In the surveys, there were revealed two irregular groundwater levels - in the Quaternary and Upper-Permian deposits. Groundwater is unconfined, the aquifer recharge is achieved by atmospheric precipitation infiltration, the upward groundwater discharge from the underlying layers. Besides, a comparative analysis of the results conducted in different years shows that the soil layers depth location, their classification and characteristics differ from each other.

\subsection{Results of the field survey of the building}

During a field survey in 2018 it was found that the maximum cracks width in reinforced concrete beams and inter-floor slabs did not increase, but there was an increase in the crack width, which previously had a less cracks width, and also there was a formation of new cracks between existing ones. The nature of the crack's development (Fig. 3) indicates simultaneous action on beams and slabs from bending moments and longitudinal tensile loads in the lower floors, and the longitudinal compressive loads in the upper floors, causing additional disclosure of cracks. The cracks development in the bearing slabs indicates the continuing deformations of the soil mass between piles, soil-cement piles and the settlement of pile foundation.

It should be noted that the grade of concrete in the structures of the surveyed building is 
sufficiently high. The compressive strength conforms to grade C25-B45 (design concrete grade B25). The measurement results are presented in Table 1. The strength checkout was carried out by the shock pulse monitoring in accordance with GOST 22690-88 by an electronic shock-pulsed meter of the strength IPS-MG4.03.

Table 1. Results of the concrete compressive strength measurement of the reinforced concrete structures.

\begin{tabular}{|c|c|c|c|c|c|}
\hline No. & $\begin{array}{c}\text { Construction } \\
\text { name }\end{array}$ & $\begin{array}{c}\text { Construction } \\
\text { coordinates }\end{array}$ & Type of concrete & $\bar{R}, \mathrm{MPa}$ & $\begin{array}{c}\text { Concrete } \\
\text { grade }\end{array}$ \\
\hline 1 & Columns & $\begin{array}{c}\text { basement, } \\
13 \text { floor }\end{array}$ & heavy & $25.1-31.3$ & B20-B25 \\
\hline 2 & Beams & $\begin{array}{c}\text { basement, } \\
1-13 \text { floors }\end{array}$ & heavy & $28.9-47.1$ & B25-B40 \\
\hline 3 & Slabs & $\begin{array}{c}\text { basement, } \\
1-13 \text { floors }\end{array}$ & heavy & $34.7-52.2$ & B30-B45 \\
\hline 4 & Walls & basement & heavy & $24.5-29.2$ & B20-B25 \\
\hline
\end{tabular}

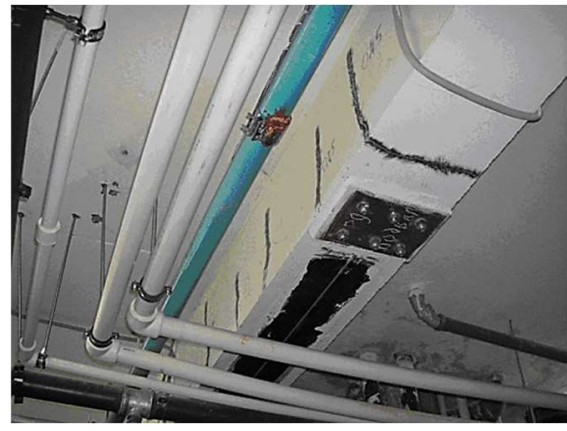

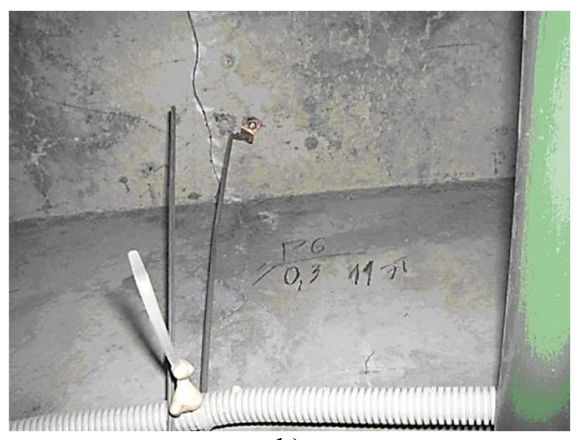

b)

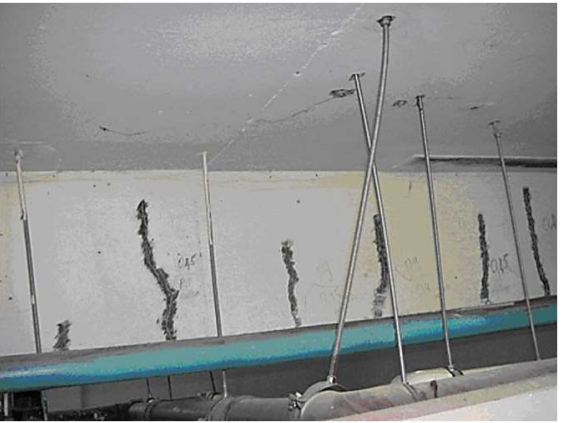

a)

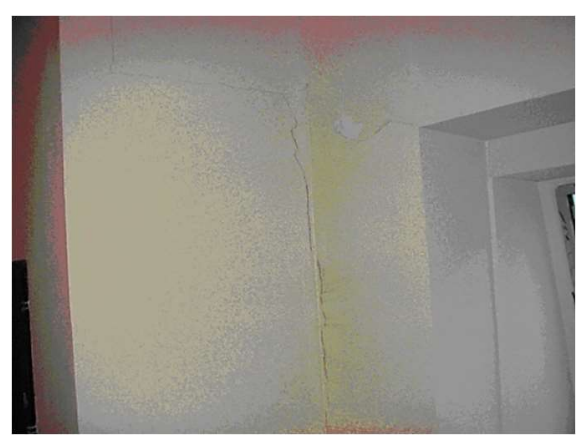

c)

Fig. 3. Cracks: a) in beams; b) in slabs; c) in walls.

\subsection{Numerical studies of the building frame stress-strain state}

For evaluation of the building system bearing capacity, the numerical studies using the Complex of Calculation Programmes such as Lira-CAD were additionally conducted. As noted in $[5-8,11,14]$, the building soil bases undergo a complex stress state, which affects the super-structure stress-strain state. Therefore, to obtain the calculation results, which are the most representative of a real behavior of the building, it is necessary to calculate the unified system «pile foundation - raft grillage - a multi-storey frame». There were created two spatial models in the calculations:

- Model 1 - model of the building frame in design state. Based on this model, there was determined a stress-deformed state of the frame, followed by checking its bearing capacity in 
the design geometric and mechanical characteristics of structural elements, foundations and soils without regard to the base strengthening of the pile foundation and the presence of defects and damage in the bearing and enclosing structures in the design loads on the building;

- Model 2 - model of the building frame, shows its actual state at the pursuance of the research. Based on this model, there was calculated a structural building system, including the pile base strengthening, the presence defects and damage in the frame bearing elements.
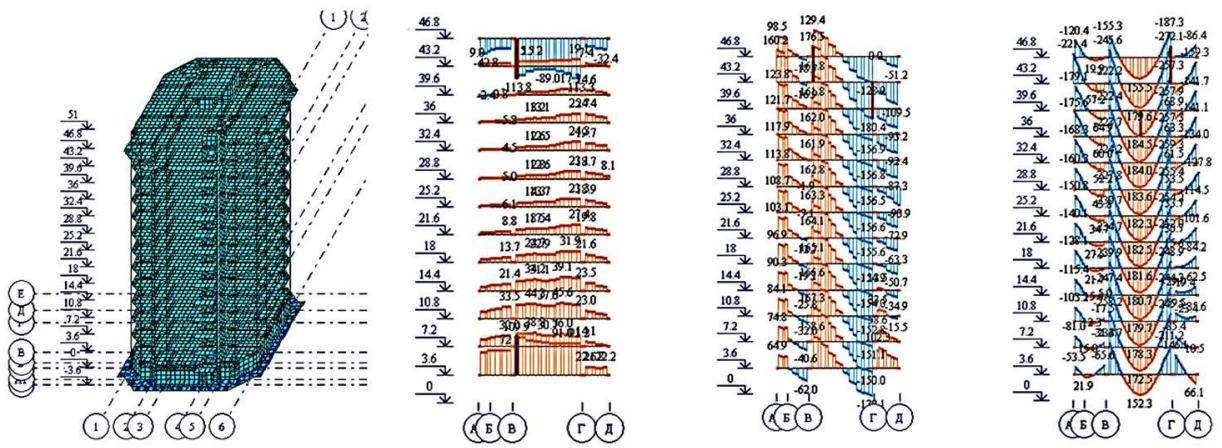

Fig. 4. Spatial analytical model of the frame and the nature of the distribution of the loads $N, q, M$ in the beams section $300 \times 800$ height along the building under the static loads (model 2).

The designed models represent a system in which columns, reinforced concrete wall envelopes - shell elements, raft grillage - elements of a thick shell. The analytical frame model is presented in Fig. 4. The presence of defects and cracks in structures was performed by introducing a reduced concrete deformation modulus, determined in accordance with the SP 63.13330.2012 «Concrete and reinforced concrete structures». The work of piles was simulated using the semigrid element system (bracings), where the rigidity was taken depending on the soil deformation characteristics and the parameters of the piles. The calculation of the yielding bracing stiffness was made on the basis of the formula [25-27]:

$$
K=P / s_{G},
$$

where $P$ is the load on the pile, $s_{\mathrm{G}}-$ the pile settlement from the load $P$, taken into account the influence of the neighboring piles according to the SP 52-102-2003 «Design and constitution of pile foundations»: $s_{G}=R_{S} s_{l}\left(R_{s}-\right.$ settlement increasing coefficient; $s_{1}-$ settlement of a single pile). The yielding bracing stiffness calculation was made for three types of piles:

- BNS 10-80 - design bored pile $10 \mathrm{~m}$ long and $800 \mathrm{~mm}$ diameter;

- BNS 5.4-80 - bored pile of non-design length (5.4 m) and $800 \mathrm{~mm}$ diameter;

- CGS 10-60 - strengthen ground-cement pile $10 \mathrm{~m}$ long and $600 \mathrm{~mm}$ diameter.

\section{Results}

The calculation results are shown in Table 2. The non-design length pile $(5.4 \mathrm{~m})$ stiffness was $6343.48 \mathrm{kN}$, which is $35 \%$ lower than the stiffness of the design pile $(10 \mathrm{~m})$. Considering the presence of collapsible loam clay under the raft grillage and the possibility of forming a gap on the junction between the raft and the soil when the latter is soaked, the entire load from the building was transferred to piles in the models.

The calculation was made on the action of permanent and temporary loads in accordance with the set of rules SP 20.13330.2016, SP 14.133302014. For accounting the strengthening stage, there was used the «Montaj» Module, which is installed into the architecture of the Lira-CAD software. Additionally, there were written codes in the $\mathrm{C}+$ language to make an evaluation of the frame bearing capacity with wind and seismic impact. The results of calculation were presented in tables 3-7 and in Fig. 4-7. 
Table 2. Summary table of pile calculation.

\begin{tabular}{|c|c|c|c|}
\hline Type of pile & $B N S 10-80$ & $B N S 5.4-80$ & $C G S 10-60$ \\
\hline $\begin{array}{c}\text { Pile load bearing capacity } F_{d}, \\
\mathrm{kN}\end{array}$ & 1412.762 & 922.842 & 897.303 \\
\hline Pile Permissible load Nd, kN & 1009.116 & 659.173 & 640.935 \\
\hline $\begin{array}{c}\text { Pile settlement } \\
S_{G}, \mathrm{M}\end{array}$ & 0.103 & 0.104 & 0.0621 \\
\hline $\begin{array}{c}\text { Stiffness of the yielding } \\
\text { bracing that simulates the } \\
\text { work of piles K, } \mathrm{kN} / \mathrm{m}\end{array}$ & 9726.606 & 6343.48 & 10305.6 \\
\hline
\end{tabular}

Table 3. Summary table of ultimate loads on piles (with consideration to strengthen base).

\begin{tabular}{|c|c|c|c|c|c|c|}
\hline \multirow[b]{2}{*}{ Model } & \multicolumn{3}{|c|}{ In design length piles $(10 \mathrm{~m})$} & \multicolumn{3}{|c|}{ In non-design length piles $(5.4 \mathrm{~m})$} \\
\hline & $\begin{array}{c}\text { permissible } \\
\text { load, } N_{d}, \mathrm{kN}\end{array}$ & $N_{\max }, \mathrm{kN}$ & $N_{\min }, \mathrm{kN}$ & $\begin{array}{l}\text { permissible } \\
\text { load, } N_{d}, \mathrm{kN}\end{array}$ & $N_{\max }, \mathrm{kN}$ & $N_{\min }, \mathrm{kN}$ \\
\hline Model 1 & \multirow{2}{*}{1009.116} & 986.7 & 533.1 & \multirow{2}{*}{659.173} & - & - \\
\hline Model 2 & & 809.8 & 655.3 & & 514.1 & 383.6 \\
\hline
\end{tabular}

Table 4. Piles strength utilisation ratio.

\begin{tabular}{|c|c|c|c|c|}
\hline Type of pile & \multicolumn{2}{|c|}{$B N S$ 10-80 (design) } & \multicolumn{2}{c|}{$B N S 5.4-80$ (non-design) } \\
\hline $\begin{array}{c}\text { Permissible load on } \\
\text { the pile } N_{d}, \mathrm{KN}\end{array}$ & \multicolumn{2}{|c|}{1009.116} & \multicolumn{2}{c|}{659.173} \\
\hline Alternative design & $\begin{array}{c}\text { Design } \\
\text { fulfillment }\end{array}$ & $\begin{array}{c}\text { Actual state } \\
\text { (with strengthening) }\end{array}$ & $\begin{array}{c}\text { Design } \\
\text { fulfillment }\end{array}$ & $\begin{array}{c}\text { Actual state } \\
\text { (with strengthening) }\end{array}$ \\
\hline $\begin{array}{c}\text { Pile maximum load } \\
N_{\max }, \mathrm{KN}\end{array}$ & 986.7 & 809.8 & - & 514.1 \\
\hline $\begin{array}{c}\text { Piles strength } \\
\text { utilization ratio } \\
K=N_{\max } / N_{d}\end{array}$ & 0.977 & 0.802 & - & 0.78 \\
\hline
\end{tabular}

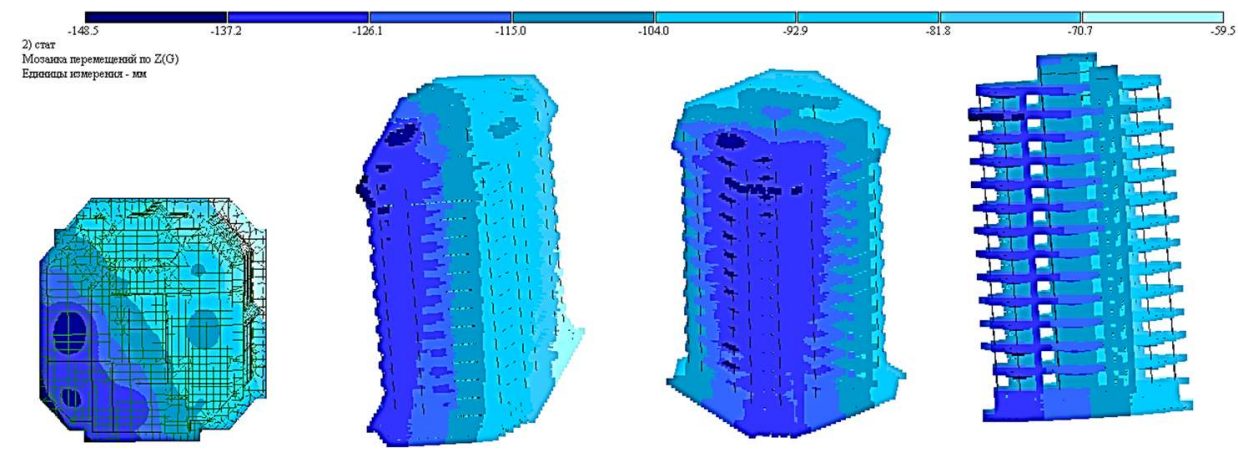

Fig. 5. Frame strain state under the static loads (model 2).

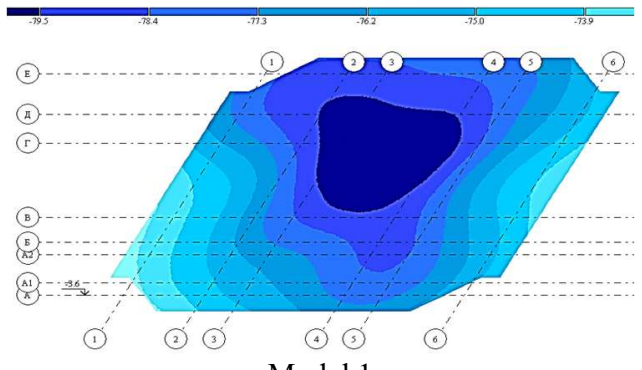

Model 1

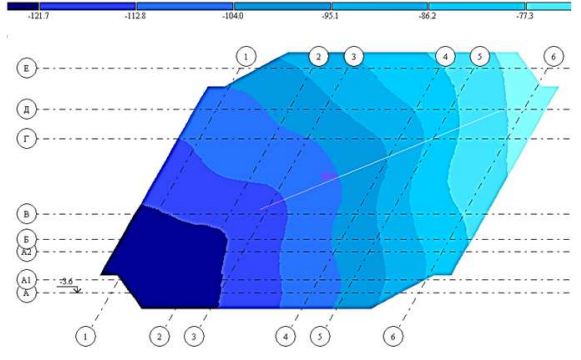

Model 2

Fig. 6. Raft grillage strain state in the design (model 1) and the actual (model 2) states. 


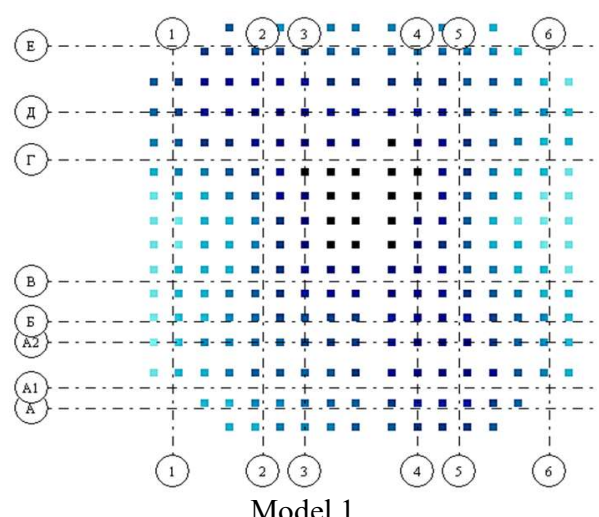

Model 1

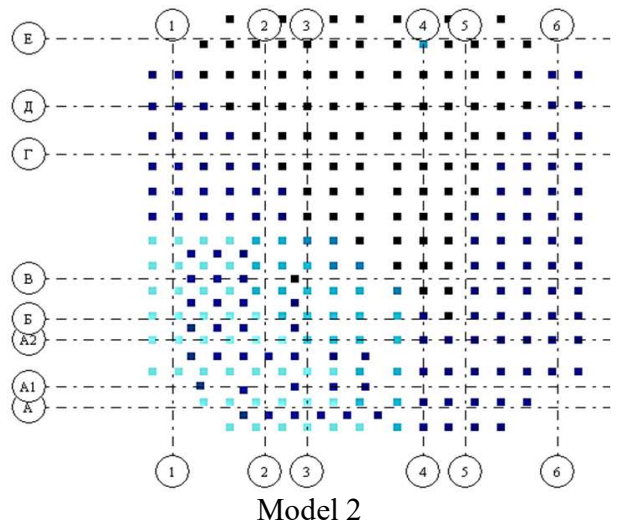

Model 2

Fig. 7. Loads distribution mosaic on piles in model 1 and model 2.

Table 5. Calculated settlements.

\begin{tabular}{|l|c|c|c|c|}
\hline \multicolumn{1}{|c|}{ Model } & $\begin{array}{c}\text { Maximum } \\
\text { settlement, mm }\end{array}$ & $\begin{array}{c}\text { Minimum } \\
\text { settlement, mm }\end{array}$ & $\begin{array}{c}\text { Mean } \\
\text { settlement, mm }\end{array}$ & $\begin{array}{c}\text { Tilt of the } \\
\text { foundation }\end{array}$ \\
\hline Design state (model 1) & 80.7 & 71.6 & 76.15 & 0.00024 \\
\hline Actual state (model 2) & 130.7 & 59.5 & 95.1 & 0.00019 \\
\hline $\begin{array}{l}\text { Limit values } \\
\text { (SP 22.13330.2016) }\end{array}$ & - & - & 150.0 & 0.003 \\
\hline
\end{tabular}

Table 6. Column strength utilisation ratio.

\begin{tabular}{|l|c|c|c|c|}
\hline \multirow{2}{*}{ Floor number } & \multicolumn{2}{|c|}{ Design state (model 1) } & \multicolumn{2}{c|}{ Actual state (model 2) } \\
\cline { 2 - 5 } & $K_{\max }$ & $K_{\min }$ & $K_{\max }$ & $K_{\min }$ \\
\hline $1^{\text {st }}$ floor & 0.886 & 0.379 & 0.972 & 0.449 \\
\hline $7^{\text {th }}$ floor & 0.589 & 0.383 & 0.652 & 0.372 \\
\hline $13^{\text {th }}$ Floor & 0.885 & 0.120 & 0.901 & 0.144 \\
\hline
\end{tabular}

Table 7. The most loaded floor beams strength utilisation ratio.

\begin{tabular}{|c|c|c|c|c|c|c|c|c|}
\hline \multirow{3}{*}{$\begin{array}{c}\text { Floor } \\
\text { number }\end{array}$} & \multicolumn{3}{|c|}{$\begin{array}{c}\text { Beams cross section } 300 \times 500 \mathrm{~mm} \\
\text { Design fulfillment } \\
\text { (model 1) }\end{array}$} & \multicolumn{2}{c|}{$\begin{array}{c}\text { Actual State } \\
\text { (model 2) }\end{array}$} & \multicolumn{2}{c|}{$\begin{array}{c}\text { Design fulfillment } \\
\text { (model 1) }\end{array}$} & \multicolumn{2}{c|}{$\begin{array}{c}\text { Actual State } \\
\text { (model 2) }\end{array}$} \\
\cline { 2 - 9 } & support & span & support & span & support & span & support & span \\
\hline 1 & 0.862 & 0.986 & 0.859 & 0.982 & 0.862 & 0.986 & 0.859 & 0.982 \\
\hline 7 & 0.74 & 0.921 & 0.733 & 0.987 & 0.74 & 0.921 & 0.733 & 0.987 \\
\hline 13 & 0.588 & 0.931 & 0.667 & 0.987 & 0.588 & 0.931 & 0.667 & 0.987 \\
\hline
\end{tabular}

\section{Conclusion}

The authors presented numerical studies of the system «pile foundation - raft grillage - a multistorey frame». Taking into account all elements joint deformation, made it possible to find the stress-strain state changing patterns of all system elements during long-term operation. The main cause of non-stationary deformation of reinforced concrete frame elements, raft grillage and pile base, is the presence of a zone with non-design length piles, and reduction of the rigidity of the base to $35 \%$ in this zone. As a consequence, there is a redistribution of the load between the pile base and reinforced concrete elements of the frame and, as a result, there are non-design additional loads in the slabs and columns, and also the building tilt increases. In monolithic reinforced concrete slabs, not only bending moments are applied, but also longitudinal tensile and compressive stresses arise, which is confirmed by the formation of new and development of existing normal and inclined cracks in these elements. 
Despite the above-mentioned processes occurring in the elements of the system «pile foundation - raft grillage - a superstructure», the bearing capacity of the combined raft-pile foundation, vertical and horizontal bearing frame elements is sufficient to perceive the existing operational loads. The combined raft-pile foundation settlements and tilts are in the design standards permissible limits.

\section{References}

1. A. Bhaduri, D. Choudhury. Serviceability-Based Finite-Element Approach on Analyzing Combined Pile-Raft Foundation, International Journal of Geomechanics 2 (20), (2020). DOI: 10.1061/(ASCE)GM.1943-5622.0001580.

2. B.G.S.T. Gamage, B. Kiriparan, B. Waduge, W.J.B.S. Fenrnado, P. Mendis. Piled Raft Foundation System for Tall Buildings, Lecture Notes in Civil Engineering 94, 353-368 (2021). DOI: 10.1007/978-981-15-7222-7_30.

3. R. Khuziakhmetov, D. Nurieva. Determination of the Reasons for the Fallof Pile Driving Machine Main Technical Near the Slope of the Foundation Pit, IOP Conf. Ser.: Mater. Sci. Eng. 890, 162304. DOI: 10.1088/1757-899X/890/1/012136.

4. R. Mangushev, A. Osokin. Construction of Deep Foundation Ditch under a Reconstructed Multi-storey, Building on the Main Avenue of St. Petersburg Procedia Engineering 189, 622-629 (2017). DOI: 10.1016/j.proeng.2017.05.099.

5. Ilizar T. Mirsayapov, I.V. Koroleva. Settlement's assessment of high-rise buildinggroundbase using transformed ground deformation diagram, Proceedings of the $15^{\text {th }}$ International Conference of the International Association for Computer Methods and Advances in Geomechanics, IACMAG-2017, 784-792 (2017).

6. T. Mirsayapov Ilizar, I.V. Koroleva. Experimental and theoretical studies of bearing capacity and deformation of reinforced soil foundations under cyclic loading, Proceedings of the International symposium, Kyoto, Japan - Computer Methods and Recent Advances in Geomechanics, Balkema. Lieden, 737-742 (2014). DOI: 10.1201/b17435-127.

7. Ilizar T. Mirsayapov, I.V. Koroleva. Bearing capacity and deformation of the base of deep foundations' ground bases. TC204 ISSMGE Seoul, Proceedings of the $8^{\text {th }}$ Int. Symposium on Geotechnical Aspects of Underground Construction in Soft Ground, 401-404 (2014).

8. Ilizar T. Mirsayapov, I.V. Koroleva. Calculation models of bearing capacity and deformation of soil foundations with vertical elements reinforced under regime cyclic loading Springer Series in Geomechanics and Geoengineering, 217729 502-507 (2019). DOI: 10.1007/978-3-319-99670-7_62.

9. Ilizar T. Mirsayapov, M.I. Shakirov. Bearing capacity and settlement of raft-pile foundations under cyclic loading, Proceedings of the $1^{\text {st }}$ International Conference on Energy Geotechnics, Energy Geotechnics, 423-428 (2016). DOI: 10.1201/b21938-67.

10. Ilizar T. Mirsayapov, Marat I. Shakirov. Combined plate-pile foundations settlement calculation under cyclic loading, IOP Conf. Series: Materials Science and Engineering 890, 1-8 (2020). DOI: 10.1088/1757-899X/890/1/012069.

11. Ilizar T. Mirsayapov, Hani M.A. Sharaf. Experimental studies of bearing capacity and settlement of foundationson clays under regime block cyclic loading, IOP Conf. Ser.: Mater. Sci. Eng. 890, 012134 V (2020).

12. I.T. Mirsayapov, N.N. Aysin. Evaluation of Subgrade Vertical Deformations of the Building with the Influence of a Deep Pit, Lecture Notes in Civil Engineering 126, 51-58 (2021). DOI: 10.1007/978-3-030-64518-2_7.

13. I.T. Mirsayapov, N.N. Aysin. Subgrade vertical deformations of a building in the zone of a deep pit influence, IOP Conference Series: Materials Science and Engineering 890 (1), 012071 (2020). DOI: 10.1088/1757-899X/890/1/012071. 
14. D.R. Safin. Experimental studies of a weak clay base reinforced with sand piles, IOP Conf. Series: Materials Science and Engineering 962, (2020). DOI: 10.1088/1757899X/962/3/032020.

15. K. Fabrichnaya. Numerical study on masonry vaults reinforced by composite, IOP Conf. Ser.: Mater. Sci. Eng. 890, 012059 (2020). DOI: 10.1088/1757-899X/890/1/012059.

16. V. Pavlov, E. Khorkov, I. Mirsayapov. Experimental research of masonry arches under the influence of the movement of supports, IOP Conf. Ser.: Mater. Sci. Eng. 890, 012052 (2020). DOI: 0.1088/1757-899X/890/1/012052.

17. I. Galiev, R. Ibragimov, A. Ashrapov, O. Radaykin. Technology for reinforcing strip foundations of reconstructed brick buildings based on computer modeling, IOP Conf. Ser.: Mater. Sci. Eng. 890, 162304 (2020). DOI: 10.1088/1757-899X/890/1/012140.

18. A. Glushkov, V. Glushko. Bases and foundations of buildings at reconstruction, IOP Conference Series: Materials Science and Engineering 365 (4), 042060 (2018). DOI: 10.1088/1757-899X/365/4/042060.

19. V. Kamskov. Analysis of the causes and recommendations on elimination of biological damage of structures during the repair and reconstruction of the State Biological Museum in Moscow, MATEC Web of Conferences 117, 00074 (2017). DOI: 10.1051/matecconf/201711700074.

20. H. Singh, P. Garg, J.N. Jha. Modeling the Response of a Piled-Raft Footing: Ultimate Bearing Capacity, Iranian Journal of Science and Technology - Transactions of Civil Engineering 45 (1), 359-371 (2021). DOI: 10.1007/s40996-020-00529-z.

21. R.M. Sulaiman Al-Ne'aimi, M.S. Hussain. Numerical modeling and parametric study of piled rafts foundations, Arabian Journal of Geosciences 14 (6), 447 (2021). DOI: 10.1007/s12517-021-06756-6.

22. Y.J. Tang, J. Pei, X.H. Zhao. Design and measurement of piled-raft foundations Proceedings of the Institution of Civil Engineers: Geotechnical Engineering 167 (5), 461475 (2014). DOI: 10.1680/geng.13.00004.

23. Q.S. Mohammed Shafiqu, R.H. Sa'ur. Behavior of piled-raft foundation under earthquake loading in various types of soil, International Journal of Civil Engineering and Technology 9 (11), 2770-2781 (2018).

24. O.S. Qaftan, T. Toma-Sabbagh, L. Weekes, L. Augusthus-Nelson. Validation of a finite element modelling approach on soil-foundation-structure interaction of a multi-storey wall-frame structure under dynamic loadings, Soil Dynamics and Earthquake Engineering 131, 106041 (2020). DOI: 10.1016/j.soildyn.2020.106041.

25. R.R. Galiullin, V.S. Izotov, D.M. Nurieva. Application of the results of numerical studies to assess the dynamic characteristics of a building with a reinforced concrete frame, Actual problems of the development of science. Collection of articles of the international scientific-practical conference. Ufa. Publishing house: Bashkir State University, 32-38 (2014).

26. A.S. Gorodetsky, I.D. Evzerov. Computer models of structures, 344 (2005).

27. A.S. Gorodetsky, L.G. Batrak, D.A. Gorodetsky, M.V. Laznyuk, S.V. Yusipenko. Calculation and design of structures of high-rise buildings from monolithic reinforced concrete, 106 (2004). 